\title{
FURTHER RADIOCARBON DATES FROM THE CATACOMBS OF ST. CALLIXTUS IN ROME
}

\author{
Leonard V Rutgers ${ }^{1} \bullet$ Klaas van der Borg ${ }^{2} \bullet$ Arie F M de Jong $^{2} \bullet$ Constance van der Linde ${ }^{3} \bullet$ \\ Jelle Prins ${ }^{4}$
}

\begin{abstract}
This paper reports a further chronological assessment of the Christian catacombs of Rome by radiocarbondated organic materials in the so-called Liberian region of the catacombs of St. Callixtus on the Appian Way. ${ }^{14} \mathrm{C}$ dates of various types of organic material are discussed and related to ages derived from numismatic evidence and epigraphic remains. The results show that this area of the catacombs of St. Callixtus is older than assumed by previous scholarship. We therefore conclude that the appellation "Liberian region" is a misnomer.
\end{abstract}

\section{INTRODUCTION}

To develop a verifiable method to date the Jewish and early Christian catacombs of ancient Rome, we radiocarbon dated small charcoal fragments scattered in the mortar of the Jewish catacombs in Rome (Rutgers et al. 2002, 2005a,b, 2006). We then proceeded by ${ }^{14} \mathrm{C}$ dating charcoal fragments as well as soot, stucco-carbonate, and human bone collagen from 2 interconnected burial rooms in the so-called "Liberian region" in the early Christian catacombs of St. Callixtus. Using the dated inscriptions contained in the burial rooms as an external chronological reference, we concluded that in a catacomb setting, collagen and soot may be well suited for a reliable dating (Rutgers et al. 2005a). In this paper, we report on our efforts to date the Liberian region in its entirety on the basis of extensive sampling, with special emphasis on collagen and soot samples. We also include samples consisting of animal collagen, textile fibers (remains of a burial shroud), charcoal, and a piece of wood. The results are discussed with respect to their internal consistency.

Prior to presenting the data, however, we briefly need to discuss the chronological value of 2 other types of archaeological materials preserved in the Liberian region of the St. Callixtus catacombsnamely, inscriptions and coins. In this area, 42 inscriptions have been found that carry a date bracketing a period from AD 276 to 428 (Ferrua 1964). Twelve of these belong to the period predating AD 350 , while 28 date to the period of AD 350-400. Only 2 inscriptions postdate this period. These inscriptions provide us with independent evidence to determine roughly when the catacomb was in use. Even so, their chronological value should not be overestimated. Only 3 inscriptions were actually found in situ. The majority of the remaining 39 inscriptions probably originate from the general area in which they were found, but there is no way to be absolutely sure of this. In addition, it should be stressed that the period covered by the epigraphic evidence, i.e. AD 276-428, does not necessarily coincide with the period that the Liberian region was in use for burials. The dates contained in the inscriptions only illustrate the habit of putting a date on an inscription. We therefore need to allow for the possibility of burials taking place in the Liberian region both before AD 276 and after AD 428.

During our explorations, we also discovered 5 coins. While 4 of these were found inside individual graves, 1 of the coins was found embedded in the mortar covering a grave (Figure 1). We have reason to assume that these coins are to be considered as in situ. They could be shown to belong to a

\footnotetext{
${ }^{1}$ Institute of History, Utrecht University, Drift 10, 3512 BS Utrecht, the Netherlands. Corresponding author. Email: Leonard.Rutgers@let.uu.nl.

${ }^{2}$ Faculty of Science, Department of Physics and Astronomy, Utrecht University, POB 80000, 3508 TA Utrecht, the Netherlands.

${ }^{3}$ Institute of History, Utrecht University, Drift 10, 3512 BS Utrecht, the Netherlands.

${ }^{4}$ Kraaipanstraat 36, 1091 PL Amsterdam, the Netherlands.
} 
period bracketing AD 295 to 387. Four of the 5 coins belong to the period predating AD 350. Unlike the inscriptions, which state with precision the year someone passed away, coins provide us with a terminus post quem only.

Figure 1 The obverse of an antonianus showing Emperor Maximianus, minted around AD 295-296 (RIC VI Cyzicus 15b). The coin was pierced and probably served as a pendant before it was placed into the mortar sealing a grave in a cubiculum of the Liberian region in the catacombs of St. Callixtus.

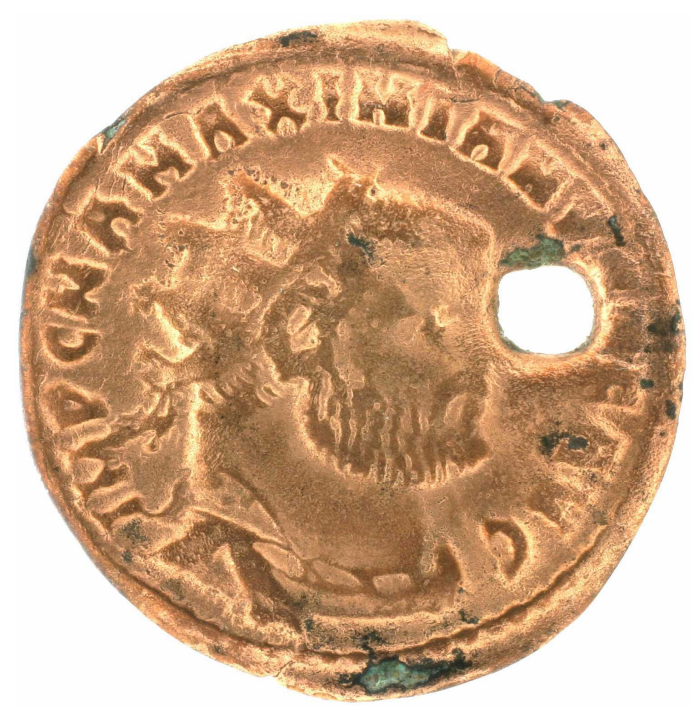

\section{METHOD AND SAMPLING}

The so-called Liberian region in the early Christian catacombs of St. Callixtus consists of an intricate network of underground galleries and burial chambers (Figure 2). Burials took place in these burial chambers, but also in the galleries connecting them. Our samples originate from the graves themselves (human collagen, textile fibers, coins) or from their decoration (soot from small lamp holes carved next to the graves; collagen from grave gifts made of animal bone pressed into the mortar of the graves).

The collagen samples derive mostly from human bone, normally extracted from teeth. Animal collagen derives from items of decoration such as bone rings. These rings served as signs of affection or recognition, and were pressed into the mortar that covered the outside of individual graves. Samples categorized as textile fibers are tiny pieces of woven fabric that have been preserved in the graves in exceptional cases and that probably served as burial shrouds (Figure 3). Soot samples consist of a thin layer of soot left behind on the walls of many catacomb galleries and burial chambers (Rutgers et al. 2005a: Figure 2).

To ensure comprehensive coverage, samples were collected throughout the Liberian region. Their identifiers (Table 1) indicate the location in the catacomb. As an example, B3-W-XIII-3 refers to gallery B3, 13th row of graves on the western wall, 3rd grave from below.

Inasmuch as the main uptake of carbon in bones and teeth occurs before humans reach adulthood (Geyh 2001), we only selected collagen for ${ }^{14} \mathrm{C}$ dating that could be demonstrated to have belonged to individuals younger than $18 \mathrm{yr}$ of age (with 2 exceptions dictated by special conditions, UtC14339 and -14342; for discussion see below). The age of the individuals was determined from the formation and eruption of the teeth, using a scheme first developed by Ubelaker (1989), and by performing the tooth cementum annulation (TCA) technique where necessary (Maat et al. 2006). Ages of individual samples have been integrated into Table 1. All samples were pretreated according to 


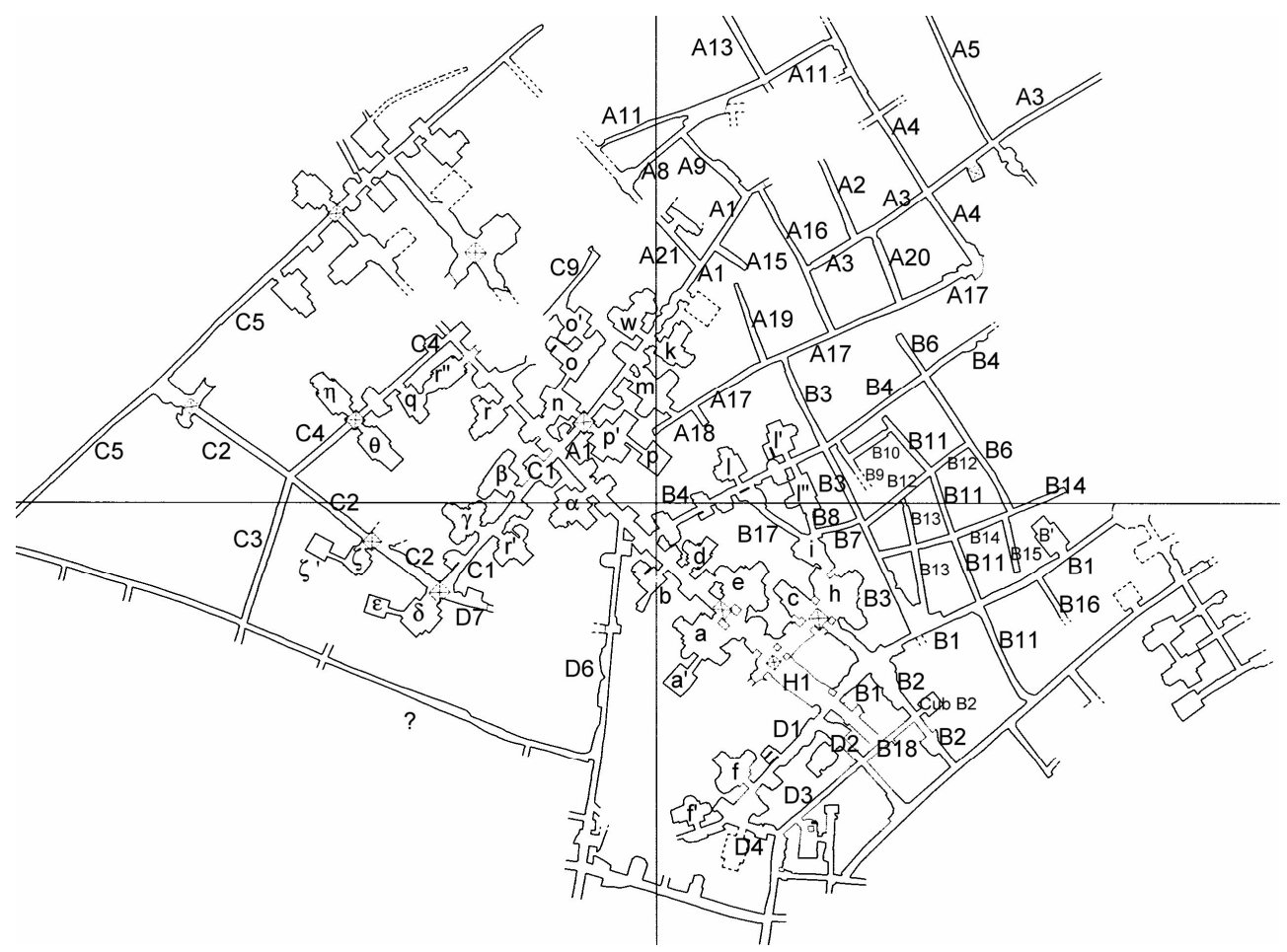

Figure 2 Plan of the Liberian region of the catacombs of St. Callixtus with designation of individual galleries and burial rooms. Reprinted with permission. (C) Leonard V Rutgers.

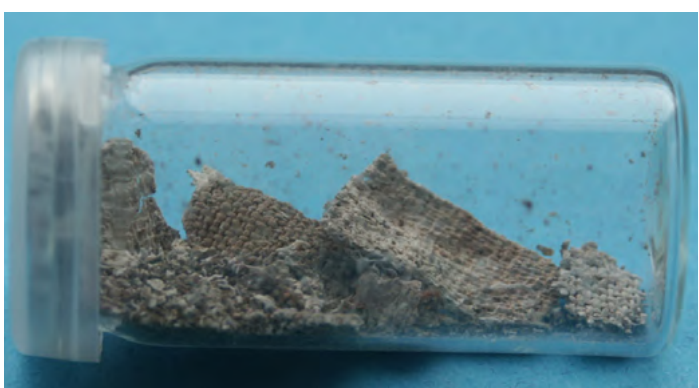

Figure 3 Cloth fragment, possibly a burial shroud, from the Liberian region of the catacombs of St. Callixtus.

standard procedures, chemical pretreatment, combustion to $\mathrm{CO}_{2}$, and subsequent reductions to graphite, which was used for ${ }^{14} \mathrm{C}$ accelerator mass spectrometry (AMS) analysis (van der Borg et al. 1997).

\section{RESULTS AND DISCUSSION}

Table 1 lists the ${ }^{14} \mathrm{C}$ ages for the 25 samples. Twelve samples have an age in the range between 1845 and 1730 BP, bracketing the calibrated time span of cal AD 70 to 410. Nine samples with an age between 10,000 and $2084 \mathrm{BP}(9800 \mathrm{cal} \mathrm{BC}$ to cal AD 60) are obviously too old for the archaeological context. Two samples ranging between 1992 and 1973 BP, bracketing a calibrated time span of $100 \mathrm{cal} \mathrm{BC}$ to cal AD 120, have an aberrant old age. It can, however, be explained. The presence in the catacomb of 2 further samples with aberrant young ages of 461 BP (cal AD 14101470) and -1495 BP (cal AD 1984-1987) can also be explained (see below). 
Table 1 Data from the Liberian region of the catacombs of St. Callixtus. "Cub." refers to cubiculum or burial room. Collagen (a): from animal bone; Collagen (h): human. The number that follows refers to the estimated age of the individual.

\begin{tabular}{|c|c|c|c|c|c|c|}
\hline Sample name & $\begin{array}{l}\text { Analyzed } \\
\text { fraction }\end{array}$ & $\begin{array}{l}\text { Mass } \\
(\mathrm{mg} \mathrm{C})\end{array}$ & $\begin{array}{l}\text { Lab code } \\
(\mathrm{UtC}-)\end{array}$ & $\begin{array}{l}\delta^{13} \mathrm{C} \\
(\% o)^{\mathrm{a}}\end{array}$ & $\begin{array}{l}\text { Age }{ }^{14} \mathrm{C} \\
(\mathrm{yr} \mathrm{BP})^{\mathrm{b}}\end{array}$ & $\begin{array}{l}2-\sigma \text { calibrated age } \\
(\mathrm{yr})\end{array}$ \\
\hline 1. B3-W-XIII-3 & Collagen (a) & 2.270 & 13409 & -16.7 & $1973 \pm 34$ & $\begin{array}{l}50 \text { cal BC-cal AD 90, } \\
110-120\end{array}$ \\
\hline 2. A1-N-III & Collagen (a) & 2.260 & 13140 & -20.4 & $461 \pm 33$ & cal AD 1410-1470 \\
\hline 3. Cub. B-a-2 & Collagen (h: 5/6) & 2.080 & 14330 & -19.9 & $1782 \pm 44$ & $\begin{array}{l}\text { cal AD 130-350, } \\
370-380\end{array}$ \\
\hline 4. Cub. N-c-6 & $\begin{array}{l}\text { Collagen } \\
\text { (h: } 10 / 11)\end{array}$ & 2.090 & 14331 & -19.3 & $1770 \pm 60$ & $\begin{array}{l}\text { cal AD 90-100, } \\
130-410\end{array}$ \\
\hline 5. H1-O-VI-2 & Soot & 0.250 & 14299 & -25.3 & $8250 \pm 120$ & $7580-7030 \mathrm{cal} \mathrm{BC}$ \\
\hline 6. H1-O-X-4 & Collagen (h: 7/8) & 2.140 & 14332 & -18.8 & $1731 \pm 43$ & $\begin{array}{l}\text { cal AD 180-190, } \\
210-420\end{array}$ \\
\hline 7. H1-O-XVII & Soot & 1.280 & 14333 & -26.3 & $6210 \pm 60$ & $5310-5020 \mathrm{cal} \mathrm{BC}$ \\
\hline 8. Staircase Fasola & Charcoal & 0.980 & 14334 & -26.0 & $-1495 \pm 35$ & cal AD 1984-1988 \\
\hline $\begin{array}{l}\text { 9. Gallery I-1 } \\
\text { Fasola }\end{array}$ & Soot & 0.610 & 14300 & -27.2 & $2621 \pm 39$ & $\begin{array}{l}890-870 \text { cal BC, } \\
850-760,680-670\end{array}$ \\
\hline 10. A1N-XIVI-6 & $\begin{array}{l}\text { Collagen (h: age } \\
\text { not known) }\end{array}$ & 2.080 & 14335 & -18.0 & $1782 \pm 49$ & cal AD 130-380 \\
\hline 11. A11-N-XIV-2 & Collagen (h: 15) & 2.080 & 14336 & -19.6 & $1751 \pm 47$ & $\begin{array}{l}\text { cal AD 140-200, } \\
210-400\end{array}$ \\
\hline 12. A3-N-XII-3 & $\begin{array}{l}\text { Collagen } \\
(\mathrm{h}:<18)\end{array}$ & 0.500 & 14301 & -19.6 & $1730 \pm 41$ & cal AD $220-410$ \\
\hline 13. A20-W-III-3 & $\begin{array}{l}\text { Collagen } \\
\text { (h: } 15 / 16 \text { or } 18)\end{array}$ & 2.100 & 14337 & -20.4 & $1804 \pm 47$ & $\begin{array}{l}\text { cal AD 90-110, } \\
120-340\end{array}$ \\
\hline 14. B2-W-VII-2 & Collagen (h: 11) & 2.070 & 14338 & -20.1 & $1752 \pm 40$ & $\begin{array}{l}\text { cal AD 140-160, } \\
170-200,210-390\end{array}$ \\
\hline 15. B6-W-XI-3 & Linen & 0.830 & 14302 & -27.5 & $1845 \pm 40$ & cal AD 70-250 \\
\hline 16. C1-Cub. b & Soot & 0.440 & 14303 & -25.6 & $3190 \pm 44$ & $\begin{array}{l}1610-1580 \mathrm{cal} \mathrm{BC}, \\
1540-1390\end{array}$ \\
\hline 17. C2-W-V-3 & $\begin{array}{l}\text { Collagen } \\
\text { (h: 41-43) }\end{array}$ & 2.060 & 14339 & -18.8 & $1787 \pm 41$ & $\begin{array}{l}\text { cal AD 130-350, } \\
370-380\end{array}$ \\
\hline 18. C4-Z-VIII-1 & Soot & 0.290 & 14304 & -22.9 & $2572 \pm 43$ & $\begin{array}{l}820-730 \mathrm{cal} \mathrm{BC}, \\
690-660,650-540\end{array}$ \\
\hline 19. Cub. Q c-4 & Wood & 0.370 & 14305 & -23.6 & $3863 \pm 46$ & $2470-2210 \mathrm{cal}$ BC \\
\hline 20. D2-Cub. & Soot & 0.430 & 14306 & -26.7 & $4860 \pm 49$ & $\begin{array}{l}3760-3630 \mathrm{cal} \mathrm{BC}, \\
3600-3530\end{array}$ \\
\hline 21. D6-N-II-2 & Soot & 0.420 & 14307 & -28.9 & $10,000 \pm 60$ & $\begin{array}{l}9800-9780 \mathrm{cal} \mathrm{BC}, \\
9770-9310\end{array}$ \\
\hline 22. D6-N-XIII-3 & Collagen (h: 8/9) & 2.110 & 14340 & -19.0 & $1756 \pm 44$ & $\begin{array}{l}\text { cal AD 140-200 } \\
210-390\end{array}$ \\
\hline 23. D9-W-XII-2 & Linen & 1.710 & 14341 & -25.3 & $1992 \pm 42$ & $\begin{array}{l}100 \text { cal BC-cal AD 90, } \\
\text { cal AD } 100-120\end{array}$ \\
\hline 23. D9-W-XII-2 & $\begin{array}{l}\text { Collagen } \\
\text { (h: 33/36) }\end{array}$ & 2.150 & 14342 & -18.7 & $1753 \pm 44$ & $\begin{array}{l}\text { cal AD 140-200 } \\
210-390\end{array}$ \\
\hline 25. D9-W.XXXIII-4 & Collagen (a) & 0.610 & 14308 & -20.0 & $2048 \pm 48$ & $180 \mathrm{cal} \mathrm{BC}-\mathrm{cal}$ AD 60 \\
\hline
\end{tabular}

${ }^{a}$ From gas mass spectrometer analysis by Department of Earth Sciences, Utrecht University.

${ }^{\mathrm{b}}$ Calibrated using CALIB v 5.0 (Stuiver et al. 2005).

In our previous study of the catacombs of St. Callixtus, we pointed out that there existed a strong chronological correspondence between one of the soot samples and a dated inscription. The soot in question was taken from a lamp hole dug into the same volcanic tuff into which the catacombs have been excavated (Rutgers et al. 2005b: UtC-13406 and Figure 2). On the basis of this particular result, we decided to collect 7 other soot samples throughout the catacomb for ${ }^{14} \mathrm{C}$ dating. 
However, the ${ }^{14} \mathrm{C}$ ages of these additional low-carbon soot samples appeared to be consistently older than the archaeological context of the catacomb (see UtC-14299, -14300, -14303, -14304, $-14306,-14307$, and -14333 in Table 1). This might indicate that the tiny amount of soot originating from the burning of oil in the lamps is contaminated with organic remains from the underlying layer of volcanic rock that could not sufficiently be removed during the chemical pretreatment (inorganic carbonates were removed with acid). In contrast to what was suggested by the previous result, this indicates that such thin, low-carbon soot layers cannot simply be used to obtain a reliable ${ }^{14} \mathrm{C}$ age (Figure 4).

Calibrated Age Ranges

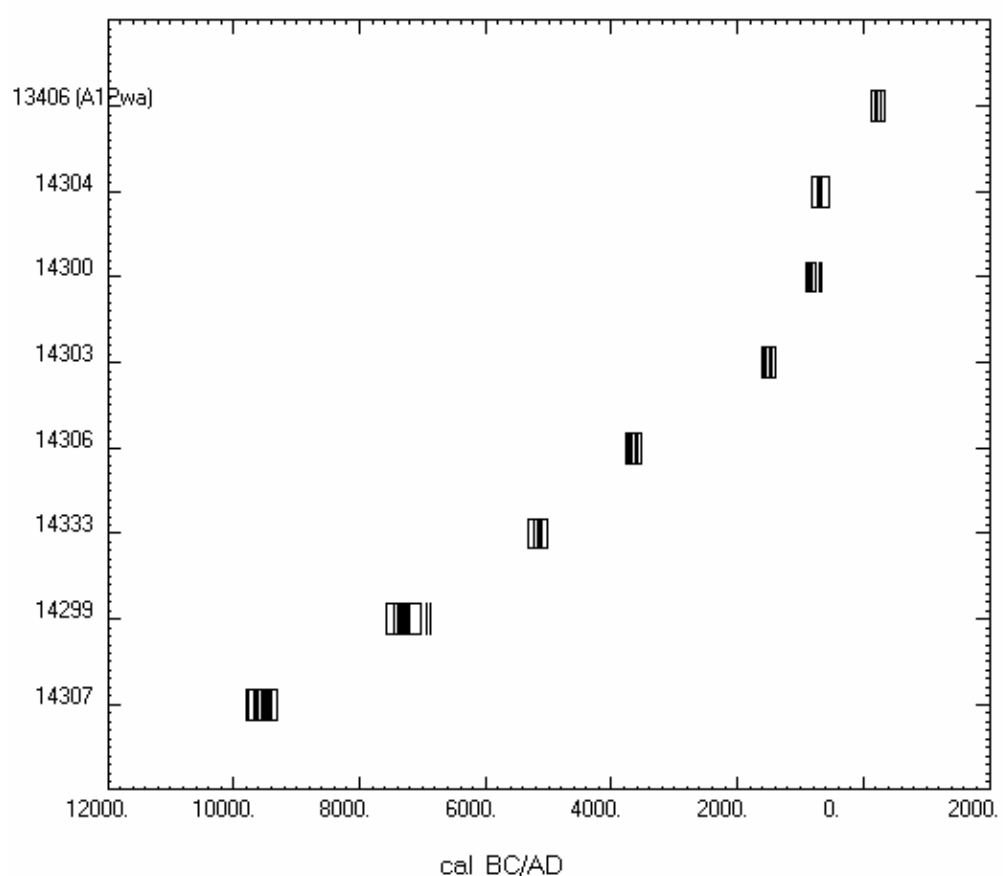

Figure 4 Calibrated ages of soot samples from the Liberian region in the catacombs of St. Callixtus. The sample UtC-13406 (A1Pwa) represents the time frame during which the catacomb was in use. All other soot samples listed here diverge strongly from that expected time frame, and too strongly to provide us with reliable chronological indicators.

It is unknown why the first soot sample (UtC-13406) resulted in a ${ }^{14} \mathrm{C}$ age that confirmed expectations. It could not have been simply the carbon content, as all 7 "unsuccessful" samples have more or less similar low carbon content. For comparison, the ${ }^{14} \mathrm{C}$ age of soot with a high carbon content (i.e. small amount of additional matrix material) collected from several fired terracotta lamps is included in Figure 5. The ${ }^{14} \mathrm{C}$ age of this carbon-rich soot was in good agreement with external archaeological considerations (Rutgers et al. 2006). It is conceivable that a variety of factors play a determinative role here-not just carbon content but perhaps also the material onto which the soot has been deposited (like the volcanic tuff, carbonate-stucco, or small rock pebbles, which tend to be either quite brittle, porous, or massive in the case of lamp holes, and fired clay in the case of the terracotta lamp). 


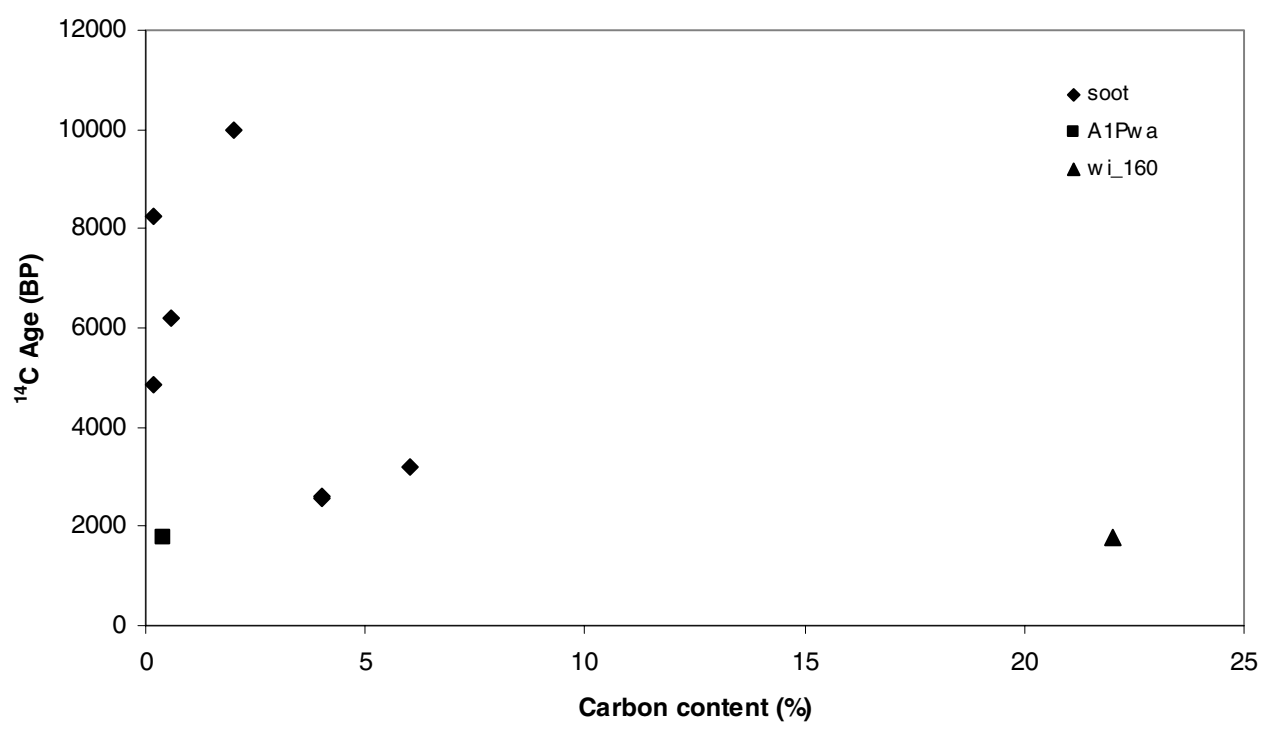

Figure 5 Carbon content of soot samples deriving from lamp holes as contained in Table 1. A1Pwa refers to a soot sample (UtC-13406) published previously in Rutgers et al. (2005b). Wi_160 refers to terracotta soot contained on a lamp published in Rutgers et al. (2006).

Collagen samples in Table 1 subdivide into 2 groups: those of animal and those of human origin. Two collagen samples (UtC-13409 and -14308) derive from animal bone rings, presumably items of decoration or toys, and were found in the mortar covering the graves. The ${ }^{14} \mathrm{C}$ age of these 2 bone rings of 1973 and $2048 \mathrm{BP}$, respectively, bracket the period of $50 \mathrm{cal} \mathrm{BC}-\mathrm{cal} \mathrm{AD} 120$ and $180 \mathrm{cal}$ BC-cal AD 160. The second sample in particular seems to be too early to fit into the expected chronological framework. On the basis of these ${ }^{14} \mathrm{C}$ results, we conclude that either the animals had a somewhat ${ }^{14} \mathrm{C}$-depleted diet, or that these items of decoration were passed on for several generations before they were finally deposited in the catacombs. From an archaeological perspective, this limits their significance for dating purposes somewhat.

Of particular interest is sample A1-N-II (UtC-13140 in Table 1). The age of this collagen, derived from a pig jaw bone (461 BP, cal 1410-1470), clearly indicates that this sample does not belong to the original contents of the grave in which it was found. Rather, it is post-depositional and must have wandered into the catacomb at a much later period in time. As is clear from contemporary graffiti on one of the walls nearby, this evidently happened in the course of the 15th century AD, during a time in which the catacomb seems to have been accessible to humans as well (Rutgers et al. 2006). Our pig jaw provides us with an excellent example of how ${ }^{14} \mathrm{C}$ dating can be used to help identify intrusive elements in the catacombs of Rome.

Eight samples in Table 1 represent human collagen from teeth belonging to individuals that had not yet reached the end of puberty (UtC-14301, -14330, -14331, -14332, and -14335-14340). Their ${ }^{14} \mathrm{C}$ ages form a coherent chronological group, ranging from 1730 to $1804 \mathrm{BP}$, thus bracketing a period of cal AD 90-410 (Figure 6). Realizing that these ${ }^{14} \mathrm{C}$ dates may have undergone some distortion as the result of a small reservoir effect caused by a diet with ${ }^{14} \mathrm{C}$-depleted food (Molto et al. 1997; Cook et al. 2001, 2002; Yoneda et al. 2002; Petchey and Green 2005), we also performed stable isotope analysis on selected bone. From this analysis, it followed that this population's dietary pattern was herbivore/carnivore, supplemented, however, with some freshwater fish. Thus, people buried in the 
Liberian region of the catacombs of St. Callixtus differed radically from their contemporaries living on the coast in nearby Isola Sacra, where a marine diet was prevalent (Prowse et al. 2004).

Calibrated Age Ranges

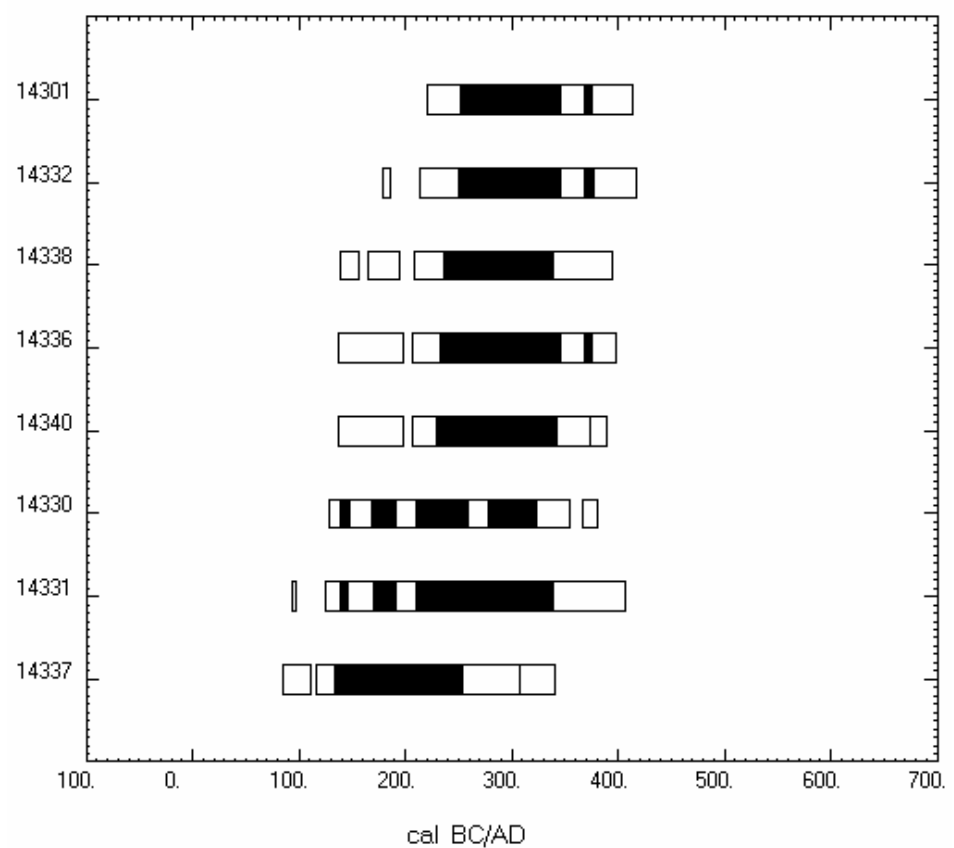

Figure 6 Calibrated ages of 8 collagen samples from human subadults preserved in the Liberian region of the St. Callixtus catacombs. The samples form a coherent group, thus suggesting that the entire Liberian region was used intensively during a relatively short span of time.

Most importantly, the ${ }^{14} \mathrm{C}$ ages of the human collagen samples are consistent with the numismatic evidence: Sample UtC-14330 (cal AD 130-350,367-80) originates from a grave that also contained a small copper coin that was minted under Constantine I, in about AD 334-337 (RIC VII Rome 355: Bruun 1966). Another sample, UtC-14331 (cal AD 90-100, 125-410), is from a grave excavated on top of another grave that was decorated with a coin from the reign of Maximianus. This second coin is datable to AD 295-296. As is evident from the pierced hole (Figure 1; RIC VI Cyzicus 15b: Sutherland and Carson 1967), this coin seems to have had an afterlife as a pendant before it ended up as decoration in the mortar of the grave in question. Although we cannot be sure, it is conceivable that the coin's piercing implies that it was used for some time before its final deposition. However, even if that was the case, the coin's dating still corresponds neatly to the dates suggested by our ${ }^{14} \mathrm{C}$ dating.

Looking at the sum probabilities for these human bone materials, we find that $96 \%$ of the samples fall into the range of cal AD 215-350 (1 $\sigma)$. Such an age range is consistent with the numismatic evidence, and is at least partially consistent with the epigraphic evidence as well. It should be noted, however, that the results of 9 out of 11 samples also can be interpreted as originating from the first half of the 3 rd century AD. This seems slightly too early when studied against the background of other chronological materials available, raising the intriguing question of whether one should allow for a small reservoir effect even in populations whose menu included some freshwater fish, but no marine fish on any regular basis. 
We also ${ }^{14} \mathrm{C}$ dated 2 tiny pieces of linen $(\mathrm{UtC}-14302$ and -14341) that were retrieved from graves in various parts of the catacombs (Figure 3). It is unusual, although not wholly exceptional, for such linen fragments to survive in the fairly humid environment of the catacombs. These pieces are most likely the remnants of shrouds used to bury the deceased (Martorelli 2000). The ages of these samples bracket a period of cal AD 70-250, $100 \mathrm{cal}$ BC-cal AD 90, and cal AD 100-120, respectively. The age of the second sample in particular seems to be a bit too old. This becomes especially evident when we compare this result with the ${ }^{14} \mathrm{C}$ age determined for the person buried in it, a 33- to 36-yrold individual (UtC-14342), whose age brackets cal AD 140-390. Since we have no reason to assume that an early dating of cloth should arouse our suspicion (Van Strydonck et al. 2004), it is conceivable that we are dealing with clothing that was worn by several generations of people before being put to use as a burial shroud. The same may apply with regard to the first linen sample.

Finally, we also ${ }^{14} \mathrm{C}$ dated (UtC-14305) an object whose composition has not yet been identified (although it is definitely not wood-it may have been some sort of toy, see Figure 7), and a piece of charcoal (UtC-14334) found near the main entrance to the Liberian region. It brackets 2466-2205 cal BC, which is obviously far too old to fit into our chronological framework. The piece of charcoal, on the other hand, dates to cal AD 1984-1987. It is likely to derive from restoration work that took place in the years following the 1980 excavation of the area in which the sample was found. Thus, it provides us with yet another good example of how ${ }^{14} \mathrm{C}$ dating can be used to identify intrusive items in archaeological settings.

Figure 7 Unidentified object from the Liberian region of the catacombs of St. Callixtus, possibly a toy (a spinning top?).

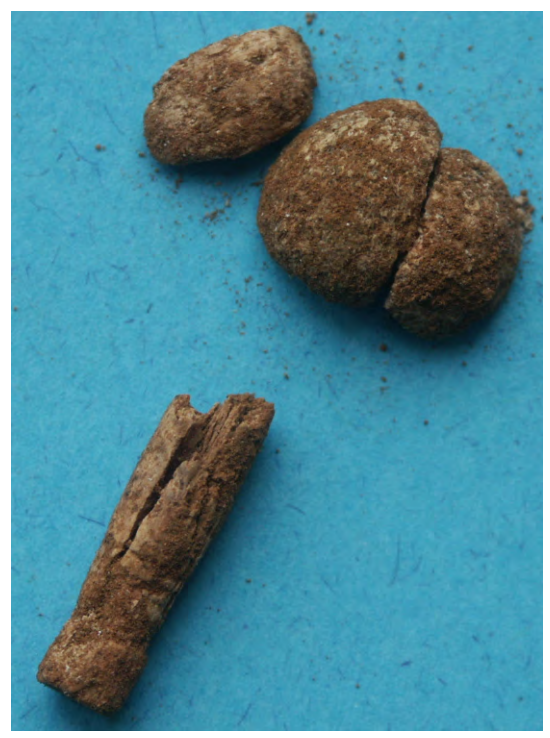

\section{CONCLUSION}

In our previous discussion of the Liberian region (Rutgers et al. 2005a), we used ${ }^{14} \mathrm{C}$ data and demographic considerations to argue that some parts of the Liberian region in the catacombs of St. Callixtus may have been in use in the second half of the 3 rd century AD. The ${ }^{14} \mathrm{C}$ data, numismatic evidence, and epigraphic remains discussed in the present contribution strongly suggest that the Liberian region in its entirety is likely to have been in use from at least the middle of the 3rd century AD onwards - that is, 1 century prior to the reign of Pope Liberius (AD 352-366), whose name has been associated with this region since the 19th century. Although there can be no doubt that this 
region was also in use during Liberius' pontificate, it is evident that burials took place there long before Liberius was ever born. Burials also continued for some time after he died-well into the early 5th century AD. We therefore conclude that the term "Liberian region," as used in previous studies on the catacombs of St. Callixtus, is chronologically and historically misleading. It should henceforth be rejected.

\section{ACKNOWLEDGMENTS}

We would like to thank the Pontificia Commissione di Archeologia Sacra for permission to study the St. Callixtus catacomb. We are particularly grateful to Fabrizio Bisconti and Raffaella Giuliani. The coins were cleaned by Ron Leenheer of the Allard Pierson Museum in Amsterdam. Figure 3 was photographed by Hans Lägers of the Utrecht "Archeologisch en Bouwhistorisch Centrum." Financial support was provided by the Netherlands Organization for Scientific Research (NWO).

\section{REFERENCES}

Bruun PM. 1966. The Roman Imperial Coinage. Volume VII: Constantine and Licinius A.D. 313-37. London: Spink \& Son. $778 \mathrm{p}$.

Cook GT, Bonsall C, Hedges REM, McSweeney K, Boroneant V, Pettitt PB. 2001. A freshwater diet-derived ${ }^{14} \mathrm{C}$ reservoir effect at the Stone Age sites in the Iron Gates Gorge. Radiocarbon 43(2A):453-60.

Cook GT, Bonsall C, Hedges REM, McSweeney K, Boroneant V, Bartosiewicz L, Pettitt PB. 2002. Problems of dating human bones from the Iron Gates. Antiquity 76(291):77-85.

Ferrua A. 1964. Inscriptiones Christianae Urbis Romae Septimo Saeculo Antiquiores. Volume IV. Rome: Pontificio Istituto di Archeologia Cristiana.

Geyh MA. 2001. Bomb radiocarbon dating of animal tissues and hair. Radiocarbon 43(2B):723-30.

Maat GJR, Gerretsen RRR, Aarents MJ. 2006. Improving the visibility of tooth cementum annulations by adjustment of the cutting angle of microscopic sections. Forensic Science International 159 (Supplement 1):95-9.

Martorelli R. 2000. Clothing in burial practice in Italy in the early Christian period. In: Pearce J, Millet M, Struck M, editors. Burial, Society and Context in the Roman World. Oxford: Oxbow. p 244-8.

Molto JE, Stewart JD, Reimer PJ. 1997. Problems in radiocarbon dating human remains from arid coastal areas: an example from the Cape region of Baja California. American Antiquity 62(3):489-507.

Petchey F, Green R. 2005. Use of three isotopes to calibrate human bone radiocarbon determinations from Kainapirina (SAC), Watom Island, Papua New Guinea. Radiocarbon 47(2):181-92.

Prowse T, Schwarcz HP, Saunders S, Macchiarelli R, Bondioli L. 2004. Isotopic paleodiet studies of skeletons from the Imperial Roman-age cemetery of Isola Sacra, Rome, Italy. Journal of Archaeological Science 31(3):259-72.
Rutgers LV, de Jong AFM, van der Borg K. 2002. Radiocarbon dates from the Jewish catacombs of Rome. $R a$ diocarbon 44(2):541-7.

Rutgers LV, van der Borg K, de Jong AFM. 2005a. Radiocarbon dates from the catacombs of St. Callixtus in Rome. Radiocarbon 47(3):395-400.

Rutgers LV, van der Borg K, de Jong AFM, Poole I. 2005b. Radiocarbon dating: Jewish inspiration of Christian catacombs. Nature 436(7049):339.

Rutgers LV, van der Borg K, de Jong AFM, Provoost A. 2006. Sul problema di come datare le catacombe ebraiche di Roma. Bulletin Antieke Beschaving 81:16984. In Italian.

Stuiver M, Reimer PJ, Reimer RW. 2005. CALIB 5.0. [WWW program and documentation]. URL: http:// calib.qub.ac.uk/calib/.

Sutherland CHV, Carson RAG. 1967. The Roman Imperial Coinage. Volume VI: From Diocletian's Reform (A.D. 294) to the Death of Maximinus (A.D. 313). London: Spink \& Son. 727 p.

Ubelaker DH. 1989. Human Skeletal Remains: Excavation, Analysis, Interpretation. 2nd edition. Chicago: Aldine. 172 p.

van der Borg K, Alderliesten C, de Jong AFM, van den Brink A, de Haas AP, Kersemaekers HJH, Raaymakers JEMJ. 1997. Precision and mass fractionation in ${ }^{14} \mathrm{C}$ analysis with AMS. Nuclear Instruments and Methods in Physics Research B 123(1-4):97-101.

Van Strydonck M, De Moor A, Bénazeth D. 2004. ${ }^{14} \mathrm{C}$ dating compared to art historical dating of Roman and Coptic textiles from Egypt. Radiocarbon 46(1):23144.

Yoneda M, Tanaka A, Shibata Y, Morita M, Uzawa K, Hirota M, Uchida M. 2002. Radiocarbon marine reservoir effect in human remains from the Kitakogane site, Hokkaido, Japan. Journal of Archaeological Science 29(5):529-36. 